\title{
Microscopic Examination of the New South African Economic Reconstruction and Post-Pandemic Recovery Plan
}

\author{
Chuks Israel Ede, Nokukhanya Jili* \\ Department of Public Administration, University of Zululand, Kwa Dlangezwa, South Africa
}

Email address:

JiliN@unizulu.ac.za (N. Jili)

${ }^{*}$ Corresponding author

To cite this article:

Chuks Israel Ede, Nokukhanya Jili. Microscopic Examination of the New South African Economic Reconstruction and Post-Pandemic Recovery Plan. Journal of Political Science and International Relations. Vol. 4, No. 2, 2021, pp. 56-65. doi: 10.11648/j.jpsir.20210402.15

Received: April 26, 2021; Accepted: May 20, 2021; Published: June 16, 2021

\begin{abstract}
South Africa is certainly not the only country affected by the novel Coronavirus pandemic in Africa - though it currently stands as the worse-hit country by the virus, but it is presently on the list of some of the countries that defiantly take advantage of the rare opportunity imbedded in the adversity of the pandemic to reset the economic landscape. The country is promptly on route to a recovery that is one-of-a-kind in the continent, from a pandemic that saw half of its GDP depleting within months. In one of his regular situational updates to the nation, President Cyril Ramaphosa announced a comprehensive Masterplan with which South Africa aims to swim against the tide of the recession caused by Coronavirus pandemic. The midmonth announcement which upheld the remaining quarter of the hapless year 2020, unveiled the new recovery Plan for the nation known as THE SOUTH AFRICAN ECONOMIC RECONSTRUCTION AND RECOVERY PLAN (ERRP). Whilst the President and the people preciously revel the new ERRP and the much-anticipated reconstruction of the economy of the country in order to address widening inequality now relapsed by the pandemic, we painstakingly examine it in detail to divulge the numerous "new" effects that inundate the decadal Plan.
\end{abstract}

Keywords: Coronavirus/COVID-19 Pandemic, Recession, Economic Reconstruction, Economic Recovery

\section{Introduction}

The advent of Coronavirus pandemic, and the incomparable scale of hardships resulting from the lockdown, exposed the height of structural inequality intrinsic in not just the social and economic spheres of South Africa but also that most SubSaharan societies and economies [9]. This obviously inspires many governments in the region to take decisive action by seizing the rare opportunity posed by the pandemic calamity to reorder or reshape their countries, societies and economies. South Africa may invariably be among top countries in Africa which take a bolder stance in overhauling the economy proses, having attempted similar recovery initiatives in past recessions, at least as available data in current democratic dispensation infer $[38,28]$. Coming in the guise of a post-pandemic recovery scheme, the latest economic reconstruction and recovery Plan reveals comprehensive structural reforms for both the South African economy and the society at large. It avails government a definitive custodian platform to expand more statutory capacity for the State in its effort to salvaging the populace from the devastating impact of COVID-19 pandemic. But is there any theoretical basis for and possibly new changes that such seemingly ill-reverse trend affords? What are the prospects for this Plan in the event of recurring waves of COVID-19 pandemic in South Africa? Before answering these penitent questions, let us understand the meaning of the common terms used in this paper.

\section{Meaning of "Microscopic Examination", "Reconstruction" and "Recovery"}

The term "microscopic" connotes a "tiny", "miniscule", "minute" or "infinitesimal" qualifier which describes the kind of examination that the new "Economic Reconstruction 
and Recovery Plan" (ERRP) of South Africa undergoes by this paper. Its etymological usage comes from "microscope", a powerful device that enhances detailed observation of tiny objects or matter through (a) lens (es) that magnify (ies) them beyond what a normal eye can see. "Microscopic examination", in this sense, relates to an in-depth examination (or inspection, investigation, analysis) of the ERRP document recently announced via its presentation to the National Assembly's October $15^{\text {th }}$ hybrid session by President Cyril Ramaphosa at the Parliament's building in Cape Town. The 38-page document, made available to the public through Government's website, comprises the country's Plan which details the strategies by which the recessive national economy will be "reconstructed" (in $\mathrm{Mr}$ President's words, "building a sustainable, resilient and inclusive economy" [29] to enable its rapid "recovery" (through "interventions to restore the economy while controlling the health risks [29] from the devastating impact of the Coronavirus or COVID-19 pandemic.

Often applicable to economies and nations that are ravaged by conflicts or unrests, the term "economic reconstruction" has been notable as "post-conflict reconstruction" since the " $18^{\text {th }}$ century" [2]. But it was not until the $19^{\text {th }}$ century that it regained prominence "due to the ever-increasing devastation of violent conflicts" [2], which suggests that the main causative factor for global economic recessions has been conflict related. From the great world wars $1 \& 2[38,14]$ to the Gulf wars that caused huge impact on oil prices leading to significant decline on economies that depended thereupon [11], major economic downturns do share parallel pedigrees whose often enduring spiral effects still boil down to one conflict or the other. Historically, the origin of economic rehabilitative efforts has also been traced to the time of Confederate Civil War in America (1861-1865), although its first application in the history of post-war was in Austria after
World War 1, with "the most impressive post-war reconstruction effort" taking place at the "end of the Second World War" [2]. Through economic reconstructive initiative, the world's governing body - from the defunct League of Nations to the present United Nations - enabled war-torn economies with certain reliefs to build "sustainable peace and stability" while laying new "foundations for economic recovery and development" [2].

\section{South Africa's Economic Recessive Antecedents Cum Recovery Strategies}

Since its attainment of a republican status in 1961 [7], South Africa has experienced at least eight major recessions although it never witnessed any war as a nation. These recessions occurred during 1974-5, 1976-7, 1982-3 and 1985. Others were in 1990, 1991-2, 2008-9 and 2016-7, according to Statistics South Africa [35]. The extant economic recession resulting from the Coronavirus pandemic is reckoned with the most devastating impact on the economy, halving the already careering economy's GDP within just the second quarter of 2020 [36]. As a nation, South Africa has however endured a very troubled past during Apartheid regime. This might explain why most of its recessive antecedents happened then with incidents of civil unrests between ruling White supremacist minorities and the mostly marginalized Black majorities, which attracted global condemnations and socioeconomic sanctions on the embattled nation. Hence, with six and three recessive antecedents occurring before and during the current democratic dispensation respectively, there is hardly enough data which covered the situation of past antecedents, unlike as there are at the present.

\section{South Africa has experienced eight recessions since 1961}

The longest ran over two years: 1991 and 1992

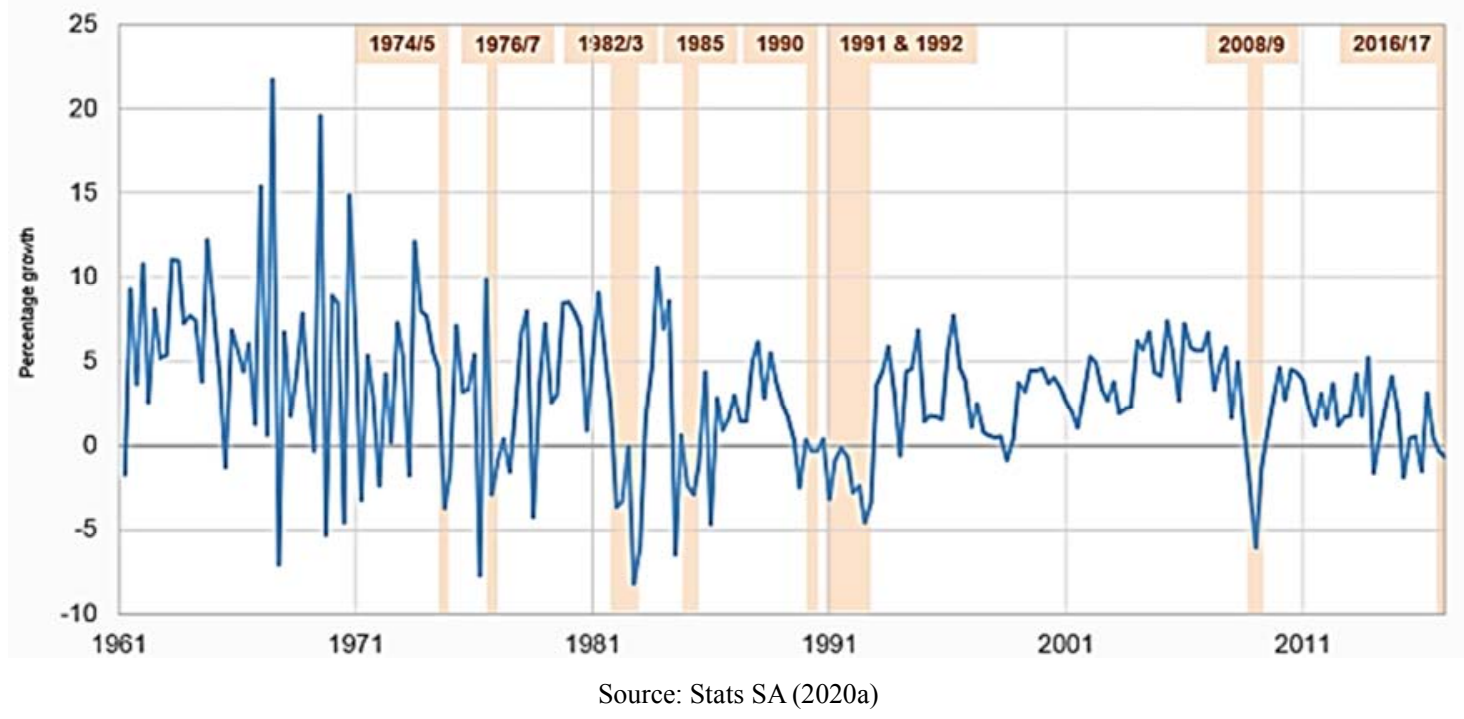

Figure 1. South Africa's recessive antecedents (1961-2017). 
According to Steytler \& Powell [38], South Africa's first ever economic recession as a democratic nation came with the 2008/09 global financial crisis that shook the whole world. Coming on the heels of the country's "longest period of sustained growth in its history [as] future growth was projected" [38], the global recession short-lived South Africa's rapid economic growth and eventually brought the economy to a standstill. Undoubtedly, the perilous economic situation must have dawned on erstwhile President, Jacob Zuma (who came into power in 2009) as an insurmountable mountain, or a mission too impossible to accomplish. This is because the aftershocks of major global recessions usually leave many developing economies on the fringes with longstanding reeling effects, hence such distressing impacts "did not reach most developing countries until 2009" [17]. For an economy like South Africa's which then grew "steadily since 1999 , with real growth averaging 5 per cent between 2003 and 2007" [38], the global economic recess of $2008 / 09$ - notably referred to as "the Great Recession of 2008-09" [22] - slashed public expenditure's growth rate "to 6.9 per cent in 2009/10" and beyond, from over $17 \%$ in less than two years [40]. The haunting effects eventually cost South Africa the status of Africa's largest economy by 2012 while national GDP shrank below $\$ 400$ billion, according to a World Bank's report in Akaonu \& Onyekwenu [1]. Public debt ostensibly rose "from 23 per cent of GDP in 2008/09 to about 40 per cent" [25] culminating in budget deficits that downed "7.3\%" of the GDP within years [38].

The economic crisis of $2016 / 17$ was also detrimental to South African economic, but not as its predecessor in 2008/09. Akanonu \& Onyekwena [1] attribute "the slump in commodity prices, tighter global financial conditions, [and] weak export demand and policy uncertainty" as main causal factors that led to the global recession which brought remarkable slowdown on Africa's leading economies like Nigeria and South Africa. According to them, the leading duo economies nearly met their Waterloo after the sudden plunge in global commodity market, with "Brent crude oil price falling to a low of $\$ 30$ per barrel in January 2016, from a high of $\$ 111.26$ in 2011" and "the plunge in gold (by 43 percent) and platinum (by 56 percent)" [1]. These signaled a horrendous blow on both economies which are reputable for their vast liquid (oil and gas) and solid (gold and platinum) minerals respectively. Meyer \& McCamel [20], for instance, remark that South Africa's "gross domestic product (GDP) lagged behind other emerging economies, shrinking to -1.2 percent in the first quarter of 2016". Worse still, they observe that the GDP became jammed as awful signs abound of its ineffectuality in "reducing unemployment", hence the gross reality of an "economy being trapped in [another] recession" within a decade [20], became a bitter pill too difficult to swallow by South Africans. The overwhelming negative effects of the recession on average South Africans got them back on the streets in protest, just as they responded in 2008/09 over "rising unemployment and hardships" [38].

In response to the 2008/09 global financial crisis, the then Motlanthe-led government came up with a national
"Framework for South Africa's Response to the International Economic Crisis" in February 2009. According to the 25page document which admitted the global recession as "the deepest and most serious economic crisis in at least the last 80 years" [28], government planned to sustain the badly hit economy through a 5-point measure that ensured the maintenance of public investments to boost socioeconomic development. These measures, which were guided by certain principles that protected the poor and vulnerable members of the South African society, promoted employment creation, infrastructural investment, fiscal sustainability and competitiveness [38], also encompassed extensive investment in public infrastructure, macro-economic policy response, industrial and trade policy measures, employment measures and social measures [28]. Details from the foremost economic recovery plan revealed "a major public investments programme of approximately R787bn" with which government intended to expand and improve the country's infrastructural development by maintaining and building new "road and rail networks, public transport, and port operations, dams, water and sanitation infrastructure, [as well as] housing construction" [28]. Government further outlined a "special National Job Initiative" through which it championed massive job creation with an additional "R10 billion over the three-year Medium Term (sic) Expenditure Framework" [28]. This was aimed at "retaining and increasing employment" - rather than letting its loss, especially in "vulnerable sectors, such as ... mining and the auto and capital equipment sectors" worse hit by the global recession, with a firm commitment to tackle "any contemplated large retrenchment in the economy... affecting more than 50 workers or those in vulnerable sectors" [28]. Overall, "special consideration ... [were also] given to... the specific needs of SMME's" as announced in the so-called "budget in time of crisis" of February 2009 [38], under former President Kgalema Motlanthe's 226-day brief administration.

Comparatively, the "technical recession" of 2016-17 may not have caused extensive damage on all sectors of the economy as its counterpart of 2008/09 eight years before [12] But it did, however, come with lingering effects that left no sector afloat, including Agriculture - no thanks to "two successive seasons of severe drought" which later cost South Africa "seven consecutive quarters of falling output [26]. Therefore, amidst the natural devastation of drought and economic recession made worse by "volatile prices in global commodity markets" [1], the South African economy defiantly "improved" with growing "confidence in early 2018" and a GDP targeted at "1.4 percent" in the same year [39]. Government's "constructive" effort in maintaining the quavering economy began to yield substantial results pronto, in sectors like mining, manufacturing, power and agriculture [19]. As a result, these "primary sectors" also became the "main drivers of [economic] growth" in 2017 [39] as the condition of global commodity markets steadily improved with "relatively competitive exchange rates of the rand" that 
stirred the GDP in 2017 and 2018 [12]. But "constructing this new South Africa" hasn't been that easy [39]. Maia [19] observed, for instance, that government's "gross loan debt stood at R2.3 trillion [just by] June 2017 - more than double the figure ... 6 years" before, even though it boosted public investment "from 1.5 per cent in 2017 to 2.8 per cent in 2019 " [26].

\section{The New Economic Reconstruction and Recovery Plan (ERRP) at a Glance}

In his introduction of the new ERRP before the National Assembly, President Cyril Ramaphosa remarks that the South African economy has been lurking in protracted stagnation (over the "past decade") and sustained low level investment and growth, coupled with the devastating impact from the novel Coronavirus pandemic [29]. Hence, his extant aim of jettisoning past regime's "construction" for a (new) "reconstruction" of the South African economy hinges on the hapless state of the economy which leaves many South Africans without job, heightens inequality and deepens poverty at all quarters of the society [29]. He, therefore, proposes a three-phased Strategy with "interventions" at restoring the economy whilst reconstructing and transforming it into a "sustainable, resilient and inclusive economy" that will address the afore named challenges, as health risks are being controlled [29]. These interventions, according to him, range from "aggressive" investment in infrastructural development, food and energy security, mass employment through grassroots reindustrialization and export promotion, and gender equality and the inclusion of more women and youth in the economy; to "green" and macro-economic interventions with a "support" for the recovery and growth of tourism sector [29].

On an interim, government earmarks R100 billion for job retention due to pandemic job losses with "provisional [budgetary] allocation of R19.6 billion" for the "creation of a cumulative 2.5 million direct jobs" désormais till 2021/22, and R50 billion to support the "most vulnerable" through social grants and food parcels/voucher distributions [29]. The pandemic's implications on the labour market inspire government's skills development initiative, to involve 100,000 "artisans" annually $-20 \%$ of which will be absorbed from the start [29]. Essentially, R12 billion is set aside for debt relief of more than 124,000 small and medium-sized enterprises with "90-day payment holidays" granted to over 2 million enterprise owners, making it "R16 billion" in total [29]. Government also plans to provide support for 34,070 businesses in the creative, cultural and sporting sector, 5,000 young entrepreneurs and micro-enterprises, and the creation of job opportunities in global business services [29]. Mass employment creation across departments and different sectors sees "environmental" expecting new 50,000 job opportunities, community forestry gets new 14,000 opportunities, while 5,531 new opportunities are up in "community health work and nursing". Others include 32,663 new jobs in municipalities across all provinces, with the protection of nearly 45,000 vulnerable teaching positions and creation of a whopping 300,000 job opportunities for teaching and school assistants [29]. Through a newly coordinating and centralized establishment, Infrastructure SA, infrastructural maintenance at grassroots level projects an impressive 25,000 new opportunities for unemployed South Africans with over 37,000 new of such opportunities in "rural roads maintenance" alone, while additional 1,560 new job opportunities are near-term for facilities, water, energy and construction of rural bridges [29].

More details from the decade long Plan reveal certain intermediate sectorial arrangements, where the energy sector is set to welcome a new "Transmission Company from a Restructured Eskom", to ease "electricity trading" in the country [29]. The sector also heralds the connection of 550 megawatt of electricity by end of 2020 with an additional 1,338 megawatt coming between January and June 2021, and another 279-megawatt following through by March 2022 . R50 million is reserved in Agricultural sector for "full commercialization of the animal health cluster portfolio" which projects a $21 \%$ turnover growth for local industries within three to five years, with creation of 317,000 new jobs through sectorial private partnership in fruits and cash crops valued at "over R80 billion" in initial gross production value. Manufacturing also receives an unspecified amount of investment for local production of additive technologies to support "manufacturing firms, especially SMMEs" - wherein over 2,160 of them (1,055 owned by women) currently benefit. With no quantified amount of investment allocated to tourism sector and a remarkable " $40 \%$ set aside for women in public procurement", government plans to support market liquidity in financial sector - with the South African Reserve Bank cutting its policy rates "by 275 basis points so far in 2020" [29]. The Bank also takes the sector through its lowest lending rates "since 1973" from a repo rate of $3.75 \%$ in May to a "policy rate [that] is now negative, well below the estimated neutral rate of $\pm 2 \%$ ", with tax incentives, deferrals, exemptions and tax reductions provided for various employees and businesses [29].

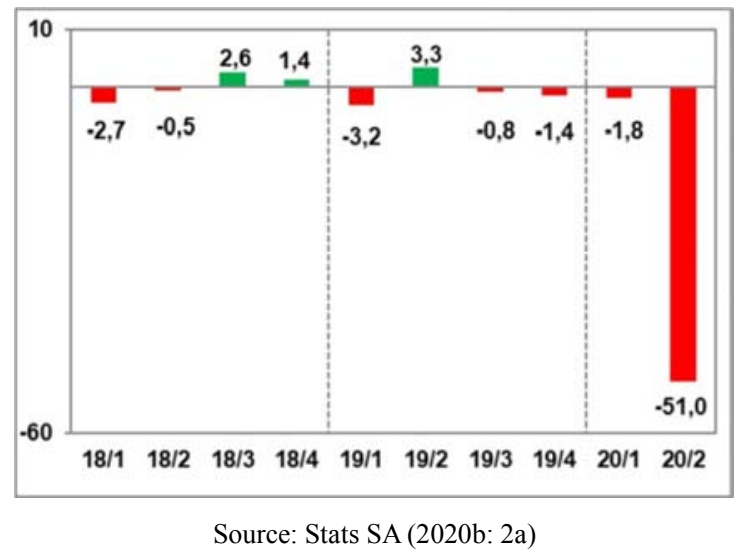

Figure 2. Situational hindsight of the South African economy (Jan., 2018 to June, 2020). 
Overall, the ERRP is expected to stimulate national economic growth that tallies up to $3 \%$ of the GDP "over the next ten years" while adding 3.6 million jobs in the same period [29]. By so doing, it strives to attain the National Development Plan - Vision 2030, which targets economic growth rate of $5.4 \%$, reduced unemployment rate of $6 \%$, investment boost of up to $30 \%$ of GDP, inequality reduction to 0.60 Gini Coefficient, with "total reduction of poverty" [29]. And although the President admits that the attainment of this Vision and indeed "certain spending commitments" hitherto planned, may be unrealistic "in the current economic context" [as] certain projects and programs will also be postponed" - no thanks to COVID-19 pandemic that halved the GDP (see Figure 2) - he is confident in ERRP's maximum attainment. He harangues his regime's determination in redoubling the efforts "to put the economy back on track ... towards the trajectory of Vision 2030" [29] by taking advantage of the opportunities presented by the adversity of a global economic recession due to COVID-19 pandemic crisis. His words:

"In adversity ... comes opportunity. South Africa is now on the threshold of an important opportunity to imaginatively ... reshape its economic landscape. The current conjuncture presents an opportunity to reset the South African economy. It is an opportunity to build a new, inclusive economy that benefits all South Africans" [29].

\section{Theoretical Underpinnings for South Africa's Economic "Reset" Amidst Pandemic Recession}

The decision by the present administration in South Africa to take advantage of current pandemic adversity to "reset" the economy, might be drawn from historical evidence of past recovery processes by major economies globally. This comes from Beaudry's [3] assertion that though the Coronavirus pandemic came as a shock to the world, it does in reality present "an opportunity". Schwab \& Malleret [32], while alluding to the World Economic Forum Conference of $3^{\text {rd }}$ June 2020 , reiterate that this opportunity will enable us to "reimagine and reset our world ... to reflect on how our economies and societies work and the ways in which they don't'. In cognizance of this latent opportunity, President Cyril Ramaphosa contrives South Africa's "reconstruction" process headlong, probably wary of his predecessor's efforts in "constructing" the economy, which culminated with an abstruse reality of heightening "unemployment, poverty, and inequalities" [23]. Ensuing public discontents over "government's failure in the delivery of vital ... services" [8] as evinced in wanton protests across the country, indicate "amongst other things a resurgence of nationalism and quests for $a$ new order that respects the [power] of politically ... diverse ... national communities and [the people]" [6], as they do resonate credence to Muchie's et al [24] earliest "Putting South Africa first" aphorism. Greene [10] expounds this "new order" in his review of Richard Florida's The Great Reset: How New Ways of Living and Working Drive PostCrash Prosperity.

According to Greene [10], post-recession economic reset generally "provides hope by suggesting a blueprint for recovery [while] stimulating creativity and innovation". Observing the ample review of Marxi's, Shumpeter's and Keynes' theories, Greene [10] conjures that "economic downturns" has an adroit means of transforming "old systems by replacing them with new ones". This is made possible by the "reconfiguration of the physical economic landscape" [10], which is commonly demonstrated when a normal device's system lags and hangs or like when an electronic equipment's powering system flops. But neither Florida nor Greene did actually coin the "reset" concept until former CEO of General Electric (Jeffery Immelt) frightfully suggested that the 2008/09 global economic crisis "was something more than a normal business cycle" [10]. Hence, like the new South African Economic Reconstruction and Recovery Plan, "The Great Reset" ideally comes in "three parts" - despite drawing retrospection from primordial Global Depressions, unlike South Africa's new ERRP. Whereas the first part focused on new structures that displaced the former structures, a striking resemblance of the historic transition into democracy from the defunct Apartheid regime, the second part exposes national potentials and adaptive tendencies during recessions to match identified "challenges facing this newest reset" inherent in part three which include the "acceptance of the pain of moving forward rather than hanging unto old system that limit development" [10].

One of the challenges that Moskovkin [22] identifies that haunt major economic systems of the world, is socioeconomic "inequality". This, she says, was made worse by the Coronavirus pandemic. Using the US as a case study, Moskovkin [22] observes how the "Corona crisis is related to Black Lives Matter protests in USA" and other countries, hence "both social issues reveal the problem of social and economic inequality" deep-rooted within global economic systems. Although she attributes these to COVID-19 pandemic, their spread demands "a return to socialist values, justice, solidarity, equality and prosperity for all" [22]. President Cyril Ramaphosa was probably mindful of this while emphasizing state's capacity as a prerequisite for a coherent and integrated planning / implementation of the new ERRP at national, provincial and local (grassroots) levels. In his words, "strengthening the capacity of the state will be among the priority areas of focus" [29], and this includes increasing public competence in the planning and implementation of most valuable capital projects with "zerotolerance approach" to corruption and mediocrity conversely, not business as usual. Ioan [13] avers that this approach is "in opposition to the ... laissez-faire" school of thought where carefree, permissive and unrestrictive means of doing things traditionally exist, with hardly any intervention by the state. John Keynes' theoretical model is idyllic and João Sicsú [33] articulates it importunately. 
According to Sicsú [33], the adjudicatory role of the state in planning and development is indispensable and practicable in a country like South Africa where "political liberties are upheld". This is because it boosts state capacity while ensuring that more opportunities exist not merely for the "prosperity of a small number of people that hold the major financial capital" [22] but for the good of all - perhaps in line with the President's determination "to build a new, inclusive economy that benefits all South Africans" [29]. This means that capitalism will no longer be realistic in the new system, and will therefore give way to a more socialist economy in South Africa. Keynes believes that capitalism suffers a great deal of failure in living up to the opportunities of national capacity to practically produce material goods that augment the GDP [33]. Hence by state's levelling intervention and increased opportunities for all and sundry, individuals stand a better chance of self-actualization in an egalitarian society, as the President assures "equitable distribution of income amongst all South Africans and ... a better life for all" [29]. This might represent government's leeway to apprehend its "entrepreneurship" plan often harangued by both past and present administrations. If so, Sicsú [33] explains that Keynes' theory does significantly favour entrepreneurs:

"Entrepreneurs produce goods, while [state] planning

is what ensures that those goods are sold. Individual

intelligence and effort are necessary to produce goods,

but collective intelligence for planning is necessary to

guarantee that the goods are sold".

This implies a somewhat top-bottom socioeconomic system that avails government a direct connectivity with every populace in order to advance their common good, rather than with a privileged few who could be easily monopolistic. While the enterprising masses are empowered to produce goods through government's support, government on the other hand plays central role in making sure that whatever is produced reaches the target consumers same way it allocates resources equitably for production of the goods. Elsewise, Sicsú [33] fears that the economy will suffer chronic failures, which is a serious pointer to the critical challenges this new socioeconomic order (or new normal) poses for South Africa as a country and the people in general.

\section{The Challenge of the "New Normal" in the Post-Pandemic Economic Recovery Process}

Whilst many South Africans kept dawdling with "Jerusalema dance challenge" unusually set in Ramaphosa's [29] "Statement on progress in the national effort to contain the COVID-19 pandemic", hardly were they mindful of the challenges bequeathing the "new normal" as exclusively buttressed in the September $16^{\text {th }}$ Presidential address. The reality of an economy half of whose GDP shrunk in the wake of a devastating global pandemic (see Figure 2), reveals a horrid acuity of the country's double dilemma, especially when it still battles another virus (HIV/AIDS epidemic) with "the largest HIV seropositive population in the world" [31]. Thus, in lieu of a higher expectation coming from both government and the global community, many South Africans might probably be oblivious of the difficult times ahead with regards to their actual obligations in a restructured economy, or worse in "what will become [our] new normal for as long as the coronavirus is with us" [27]. And whereas we anticipate a much bigger role from the government in orientating and sensitizing the masses on their position and responsibility - in the premise of "to whom much is given (or takes much), much is expected" - the fear of South Africa's bad record in epidemic management turning worse in pandemic management, remains an inexorable nightmare.

Nonetheless, the "new normal" most likely will represent the dawn of a new era since things may not continue the same way they were. Hence, with "new" allegories inundating the Economic Reconstruction and Recovery Plan to demonstrate the magnitude or margins of novelty, hardly will one flip of ERRP's page ensue without a glare of at least one "new" qualifier. From "new sources of growth and... industrial development" stimulants, the skilling of "new artisans " and "licensing of spectrum ... for new entrants" with new materials to build "a globally competitive manufacturing sector" by a new "Artificial Intelligence Institute", President Ramaphosa's optimism gushes further to soon churn out millions of "new green jobs, industries and firms" in "a new economy" that "embraces new entrants and capacity into the energy space" through the "development of new regional generation and transmission infrastructure" [29] As much as all these "new developments" are very alluring, they may barely be accomplished by a government and people in a country that is not willing to also imbibe new mindset and course of action, because there is no purer description of self-delusion than when a person does things the same old way while expecting new outcomes.

\section{7. "New" National Development Trajectory with Potential Through the ERRP}

One of the main highlights of the new Economic Reconstruction and Recovery Plan is "industrialization through localization" [29]. According to President Ramaphosa, government will "kick-start a massive program of industrialization" through direct expansion of indigenous manufacturing capacity with a view to reducing importation of goods while developing a newly competitive export sector for "sale of South African made products" [29]. The program will prioritize largescale domestic production in areas like "construction, agro-processing, health-care", equipment and industrial inputs, where the country has "existing capacity or a competitive advantage" [29]. Others are "basic consumer goods", "transport rolling stock focusing on automobile and rail assembly component production" and the building of new "minerals value chains" through the "identification of strategic [natural resources] that will be designated for local 
beneficiation" [29]. While it primarily boosts SMMEs' participation "in the manufacturing value chain", "light and fast consumer goods manufacturing" and "high-demand minerals [processing] such as chrome and ferrochrome" at grassroots (township) level, government plans to collaborate with private sector in transforming "dormant industrial production infrastructure" to enhance "localization" while maintaining the "investment pipeline momentum" of the program through Special Economic Zones [29].



Figure 3. The Industrial Localization program's process. Source: RSA (2020: 13).

Figure 3 reveals that the "industrialization through localization" policy was nursed since 2014, though President Ramaphosa projects it in furtherance of the nation's core post-pandemic development pursuit. The President buttresses its inevitability in restoring the economy from deep-seated recession and reshaping the country into an exquisite productive hub capable of meeting both local and national demands, and probably contributing meaningfully to subregional, continental, and global value chain. But could the imaginable "opportunity" which government projects at global scene, divests it of the awareness of any accompanying uncertainty? By emphasizing "import replacement" with "local manufacturing" [29] to rightly promote a competitive export for South African goods, how does the President trust that no such parallel policy response also emanates within subregional and continental or at global level? Interestingly, President Ramaphosa truly admits the "risks [of] amplifying nationalism and unilateral initiatives" [29] pari-passu his anti-foreign importation but pro- exportation scheme. His word: "protectionism is likely to grow" - already leaks his indulgence on the odds of similar policy invention by other countries, which he does agree will cause "global trade ... to slow and global value chains ... to be reconfigured", yet President Ramaphosa is bent on taking "advantage of the opportunities presented by the global economy" with such gusto that nearly defied Parliament's calming during the October $15^{\text {th }}$ ERRP's presentation [29]. Surprisingly enough, he aptly concedes that the same global economy "is also on the mend" [29].

\section{Illusive Expectations on the Global Economy}

The sad reality of the devastating impact of COVID-19 on global economy, casts more doubt on any possibility of an early recovery by most economies around the world. The implication for South Africa whose trading partners stretch 
across Asia, Europe, the Americas and other parts of the world [30], is that its economic recovery process may lag as international economic relations remain nominal if not wholly abysmal, pending substantive recovery effort in those countries. An update from Asian Development Bank on the situation in Asia, for instance, reveals that the economies in the world's most populous continent now face an unprecedented contraction in 60 years [16], with partners like India and others bearing the brunt. Countries like Russia and Turkey - South Africa's leading trading partners in Europe are also "affected by COVID-19 economic shock" as European economies contract by $7.0 \%$ [40], compared to the 9.4\% contraction for Latin American economies where Brazil and Mexico "are being negatively affected" [5]. Caribbean nations, on the other hand, now "face deep economic recessions, with ... gross domestic product decline of $10.3 \%$ " [5]. The situation in Africa is also not palatable, as the effect could "lead to a contraction in real GDP growth rate of $-1.7 \%$ in 2020 in the baseline scenario and $-3.4 \%$ in the worse-case scenario" [21].

With such global scale of COVID impact across all continents, there is a higher likelihood that real economic growth might be farfetched within the affected economies. The unusual expectation on any of these countries in terms of tangible trade or investment, comes with grave uncertainties that could jeopardize foreseeable economic growth for South Africa and the Presidential Economic Team is probably not unaware. Appreciatively, President Ramaphosa's "green" economic agenda [29] presents clues for a sustainable economic recovery and development initiative that depends more on inherent national potentials than imaginary opportunities elsewhere. Probably drawing from Khan et al [15] "green ideology" which helps emerging Asian economies attain sustainable development through environmental-friendly policies, or Luukkanen et al [18] "Green economic development" theory which provides a "sustainable" window of opportunity for "green growth productivity" to "addresses gaps and weak points in trends related to economic, environmental and societal development" [18]. The South African "green" economic development agenda specifies "renewable" potentials that foster the desired growth and development with controllable or "risk-adjusted" tactic which ensures that no aspect of the economy or the public progresses at the expense of the other.

\section{The Mirage of South Africa's Economic Recovery amid Recurring Waves of COVID-19 Pandemic}

Although President Ramaphosa's "green" economic strategy "entails building a sustainable ... and inclusive economy" [29], it embodies no concrete plan in case of any event of recurrent waves of the pandemic in South Africa. As much as it is most undesirable, chances of a second wave even third and fourth waves of COVID-19 pandemic are rife, and instances in Europe and America are undeniable proofs to the sad reality [34, 4]. Alternately, there is also a possibility that the initial waves become umpteenth with little chances of subsiding - instead - an unceasing surge in both positive cases and casualties. Either way, the implication spells doom for the country's economic recovery effort - let alone its national reconstruction initiative. There is, therefore, an urgent need for a national contingency plan with practical arrangements to effectively manage the Coronavirus pandemic in the wake of any resurgence in near or far future. Add-on strategies should also provide specific arrangements, like vaccinations, to tackle the dreaded pandemic proactively, as opposed to the trailing effort that is more or less reactive. Stringent policies might also require strict socioeconomic compliance on the part of the citizenry to evade a possible return to higher lockdown levels, on the basis that such precautionary avoidance is far better than associated cost of another full lockdown.

\section{Conclusion}

The Coronavirus pandemic causes unparalleled scale of diminution on South Africa's economy. This is why the President seizes the opportunity presented by the adversity to press the country's "restart" or refresh button in order to usher in a new economy that will benefit all and sundry in the country. The new South African Economic Reconstruction and Recovery Plan thus promises new opportunities and potentials for the creation of new jobs in their millions. It also elaborates a "new" national development trajectory through which the country's local manufacturing capacity is boosted for enhanced competitive advantage in global economics. Fundamentally, the Plan presents a new socioeconomic order for the country - somewhat different from the extant capitalist ideology which seems to benefit some privileged few. It charts an inclusive economy with sustainable structures that ensures renewable growth uppers that will ideally favor everybody in the country. What it does not disclose, however, is that these uppers or so-called sustainable stimulants could be derivatives of heavy government borrowings that boil down to enormous public debs for the country. The resultant risk of a high tax in these critical times and in years ahead - and its punitive implications on the taxed masses - are better not under our scope of examination. And whereas few traces of typographic errors in the ERRP may probably be unnoticed or easily forgiven, crucial projections (like in Energy sector, etc.) may not - especially as inherent crisis in such sectors alerts the importunity of complete overhauls.

Nonetheless, Africa's worst-hit country by COVID leaps for a significant rebound - thanks to the all-inclusive ERRP which incorporates many "new" projections for the country. As South Africa heralds a new era of economic development in the country, the onus is now on the masses to imbibe new attitude and mindset in order to usher in new and restructured society and economy. 


\section{References}

[1] Akanonu, P. C. and Onyekwena, C., 2016. A note on the economic downturn in Sub-Saharan Africa: the Nigeria-South Africa comparison. Abuja: Centre for the Study of Economies of Africa.

[2] Alimba, N. C. \& Chima, J. 2017. Methodological Issues in Peacebuilding and Reconstruction: Lessons for Nigeria. American International Journal of Humanities and Social Science, 3 (5), pp. 29-43.

[3] Beaudry, P., 2020. The Great Reset. Victoria: Bank of Canada.

[4] Cacciapaglia, G., Cot, C. and Sannino, F., 2020. Second wave COVID-19 pandemics in Europe: a temporal playbook. Scientific reports, 10 (1), pp. 1-8.

[5] CRS. 2020. Latin America and the Caribbean: Impact of COVID-19. Washington D. C.: Congressional Research Service. Retrieved from https://fas.org/sgp/crs/row/IF11581.pdf on 15/11/2020, $1: 31 \mathrm{pm}$.

[6] Dunford, M. and Qi, B., 2020. Global reset: COVID-19, systemic rivalry and the global order. Research in Globalization, 2, p. 100021.

[7] Ede, C. I. 2017. An Assessment of Government's National Youth Policies' Impact on Entrepreneurship Development of Unemployed Youths at Grassroots Level in Empangeni. Thesis: Master's, Department of Public Administration, University of Zululand, South Africa.

[8] Ede, C. I. and Jili, N. N., Service Delivery with Wanton Protests in Megalopolises, South Africa. Indexing \& Abstracting, p. 50-60.

[9] Finn, B. M. and Kobayashi, L. C., 2020. Structural inequality in the time of COVID-19: Urbanization, segregation, and pandemic control in Sub-Saharan Africa. Dialogues in Human Geography, 10 (2), pp. 217-220.

[10] Greene, R., 2011. A Review of "The Great Reset: How New Ways of Living and Working Drive Post-Crash Prosperity" Richard Florida. New York: HarperCollins, 2010. 225 pp. (ISBN 978-0-06193-719-4). Annals of the American Geographers, Vol 101, No. 3 (May 2011), pp. 698-700.

[11] Grusky, D. B., Western, B. and Wimer, C. eds., 2011. The great recession. Russell Sage Foundation.

[12] IDC. 2017. Economic overview: Recent developments in the global and South African economies. Johannesburg: Industrial Development Corporation.

[13] Ioan, G., 2012. Theoretical Models of Economic Recovery in Recession and Depression Phases. EIRP Proceedings, 7.

[14] Islam, I. and Verick, S., 2011. The great recession of 2008-09: Causes, consequences and policy responses. In From the great recession to labour market recovery (pp. 19-52). Palgrave Macmillan, London.

[15] Khan, S. A. R., Sharif, A., Golpîra, H. and Kumar, A., 2019. A green ideology in Asian emerging economies: From environmental policy and sustainable development. Sustainable Development, 27 (6), pp. 1063-1075.

[16] Kuroda, H. 2020. COVID-19 and the Global Economy: Impact and Challenges - From Asia's Perspective. Speech at the 62nd Annual Meeting of the National Association for Business Economics. Tokyo: Bank of Japan.

[17] Lewis, M. and Verhoeven, M., 2010. Financial crises and social spending: The impact of the 2008-2009 crisis. Available at SSRN 1670341.

[18] Luukkanen, J., Kaivo-oja, J., Vähäkari, N., O’Mahony, T., Korkeakoski, M., Panula-Ontto, J., Phonhalath, K., Nanthavong, K., Reincke, K., Vehmas, J. and Hogarth, N., 2019. Green economic development in Lao PDR: A sustainability window analysis of Green Growth Productivity and the Efficiency Gap. Journal of cleaner production, 211, pp. 818-829.

[19] Maia, J. "Trends in and outlook for the global and South African economies". A presentation at the $6^{\text {th }}$ Conference themed "Ideas that Work for Industrial Development" held on $5^{\text {th }}$ to $6^{\text {th }}$ October, 2017 at Pretoria East by the Council of Scientific \& Industrial Research.

[20] Meyer, D. F. and Mc Camel, R. T., 2017. A time series analysis of the relationship between manufacturing, economic growth and employment in South Africa. Journal of Advanced Research in Law and Economics, 8 (4 (26)), pp. 1206-1218.

[21] Morsy, H., Balma, L. and Mukasa, A. N., 2020. 'Not a Good Time': Economic Impact of COVID-19 in Africa. Working Paper Series 338. African Development Bank Group. URL: http://www.afdb.org/fr/documents/working-paper-338-notgood-time-economic-impact-COVID-19-africa.

[22] Moskovkin, V. M., 2020. Do We Need a Great Reset? COVID-19, Black Revolution, Inequality and Common Good. Beacon J Stud Ideol Ment Dimens, 3 (1), p. 011310115.

[23] Mubecua, M. A. and David, O. J., 2019. So far so good? Tracking the poverty eradication goal of SDGs in Kenya, Nigeria, and South Africa. Journal of Public Affairs, 19 (4), p. e1964.

[24] Muchie, M., Gammeltoft, P. and Lundvall, B. A., 2003. Putting Africa First. The making of African innovation systems.

[25] National Treasury. 2010. Budget Speech 2010: Minister of Finance Pravin Gordhan. Pretoria: The National Treasury, Republic of South Africa.

[26] National Treasury. 2017. 2017 Budget Review. Pretoria: The National Treasury, Republic of South Africa.

[27] Ramaphosa, C. 2020. Statement by President Cyril Ramaphosa on Progress in the National effort to contain the COVID-19 Pandemic. Pretoria: Government Publications. Retrieved 2020/11/04 12:29pm from The Directorate for Consular Services: http://www.dirco.gov.za/docs/speeches/2020/cram0916.pdf.

[28] RSA. 2009. Framework for South Africa's Response to the International Economic Crisis. Pretoria: Government Publications.

[29] RSA. 2020. The South African Economic Reconstruction and Recovery Plan. Pretoria: Government Publications.

[30] Roux, A., 2016. Everyone's Guide to the South African Economy 12th edition. Randburg 2193: Penguin Random House South Africa. 
[31] Satoh, S. and Boyer, E., 2019. HIV in South Africa. The Lancet, 394 (10197), p. 467.

[32] Schwab, K. and Malleret, T., COVID-19: The Great Reset (Geneva: WEF, 2020), e-book.

[33] Sicsú, J., 2020. Keynes's state planning: from bolshevism to The General Theory. The European Journal of the History of Economic Thought, pp. 1-23.

[34] Solis, J., Franco-Paredes, C., Henao-Martínez, A. F., Krsak, M and Zimmer, S. M., 2020. Structural vulnerability in the united states revealed in three waves of novel coronavirus disease (COVID-19). The American journal of tropical medicine and hygiene, p. tpmd200391.

[35] Stats SA. 2020a. The South African Economy shrinks by 0.7\%. Published online: http://www.statssa.gov.za/?p=9989 Retrieved: 07/10/2020 at 05:56am.
[36] Stats SA. 2020b. Gross domestic product: Second Quarter 2020. Statistical Release P0441. Pretoria: Statistics South Africa.

[37] Stavytskyy, A., Giedraitis, V., Sakalauskas, D. and Huettinger, M., 2016. Economic crises and emission of pollutants: a historical review of select economies amid two economic recessions. Ekonomika (Economics), 95 (1), pp. 7-21.

[38] Steytler, N. and Powell, D., 2010. The impact of the global financial crisis on decentralized government in South Africa. L' Europe en Formation, (4), pp. 149-172.

[39] The World Bank. 2018. South Africa economic update: Jobs and inequality. Washington D. C: The World Bank.

[40] UNCTAD. 2020. Trade and Development Report 2020. Geneva: United Nations. 